\title{
Comparative Analysis of the Risk-Return Characteristics of Office and Shop Property Investments in Osogbo, Nigeria
}

\author{
Daniel Ibrahim Dabara* ${ }^{1}$ Anthony Ikpeme Ankeli ${ }^{1}$ Adeleye Gbenga Odewande ${ }^{1}$ Joshua Guyimu $^{2}$ \& Adeleke \\ Moses Adegbile ${ }^{3}$ \\ 1. Department of Estate Management, Federal Polytechnic, Ede, PMB 231, Osun State, Nigeria \\ 2. Federal Ministry of Lands, Housing and Urban Development, Mabushi, Abuja, Nigeria. \\ 3. Estate Management and Valuation Department, The Polytechnic, Ibadan, Oyo State, Nigeria \\ * E-mail of the corresponding author: dabara2000@yahoo.com
}

\begin{abstract}
This study aims at examining the risk-return characteristics of commercial real estate investments in Osogbo Nigeria. Primary data used for this study was obtained through questionnaire survey. A total enumeration survey of all the estate surveying and valuation firms in the study area was carried out. The data collected was used to calculate the income, capital and total returns on investments in commercial properties in Osogbo. Furthermore, descriptive statistics was used to determine the asset returns and asset risk of the selected investment assets. This involved the use of weighted means, percentages and Standard deviations. The study revealed that investments in commercial properties in the study area provided a continuous positive rate of returns ranging between $3.12 \%$ and $34.35 \%$ while the corresponding risk ranged between $1.50 \%$ and $10.11 \%$. The investment information provided in this study has significant implication for both local and foreign investors desiring to invest in the Nigerian property market.
\end{abstract}

Keywords: Asset, Return, Risk, Investment, Portfolio.

\section{Introduction}

An investment can be simply defined as expenditure in cash or its equivalent during one or more time periods in anticipation of enjoying a net inflow of cash or its equivalent in some future time period (Ballantine \& Stray, 1998; Koen \& Monique, 2010). In view of the limited resources and divers' investment alternatives available to an investor, Marquard \& Von-Eije (2006) posited that investment decisions are necessary. The authors further asserted that investment decisions are made as a result of assumptions, expectations and predictions of the future. Consequently, there is usually inherent uncertainty about future returns and risk complexities. Therefore, it is very important for investors to first ascertain the risk-return characteristics of an investment asset as good as possible before committing investment funds to such investment(s).

Investors' informed decisions with respect to the risk-return strategies of real estate investments provide many benefits. It can provide diversification benefits; has low historical correlations to other asset classes; provides current income and the potential for capital appreciation; hedges inflation with returns that equals or exceeds the rate of inflation over longer periods of time; and has the capacity to produce superior risk-adjusted returns relative to other investments asset classes (Hui \& Eddie, 2009; Steinke, 2011; Fiorilla \& Halle, 2011).

The aim of this study is to examine in a comparative context, the risk-return characteristics of commercial real estate investments in Osogbo metropolis, Nigeria. To achieve the foregoing, the researchers sought for answers to the following questions: What were the return characteristics of office and shop properties in the study area between 2002 and 2012? What were the risk characteristics of office and shop properties in the study area between 2002 and 2012? And is there any relationship between risk and returns on office and shop properties in the study area? The remaining part of the study is presented as follows: the next section presents review of related literature, section three presents the methodological approach adopted for the study, the result/discussion was presented in section four, while section five presented summary of findings, policy implication and conclusion.

\section{Literature Review}

According to Rahmann \& woolston (2011), commercial real estate investment is usually rental properties intended to generate a return from rental income and/or capital appreciation. Commercial property types as noted by Fiorilla \& Halle (2011) are: office, retail, multi-family, industrial and hotel, self-storage, seniors housing and health care among others. Investments in these real estate assets are associate with multiple risk complexities which includes: investment illiquidity, asset value volatility, asset valuation inaccuracies, leverage-amplifying 
negative performance during falling markets, limited/ imperfect benchmarks to gauge closed-end fund performance, combination of a large lot size (capital intensive investments) and high transaction costs (Hoesli \& Lekander, 2008; Rahmann \& woolston, 2011).

Besides, direct real estate investments are management intensive over the whole property cycle, which is demanding expertise regarding a range of fields from the investors (Steinke, 2011). Similarly, due to lack of frequent transaction data, real estate marketplaces generally have low transparency which induces information asymmetries between the market participants (Georgiev \& Georgi, 2003). All these challenges are further reinforced considering transnational investments, since different market practices, laws, taxation, currency, inflation rates, and cultures must be considered (Hoesli \& Lekander, 2008). However, measurement issues, market opacity, and other aspects of uncertainty affecting both direct and indirect real estate investments, combined with the above mentioned drawbacks makes commercial real estate investments a very risky business for investors.

Despite its inherent risks, commercial real estate presents a compelling opportunity for investors. Not only does the sector provide many long-term investment benefits, including healthy income returns and a hedge against inflation, but fundamental factors such as the improvement of the risk/return characteristics of the overall mixedasset portfolio (Thambiah \& Foscari, 2011; Fiorilla \& Halle, 2011).

Conner (2010) and Payton (2011) observed that the case for investing in commercial real estate looks particularly attractive when viewed in the context of the current market environment, although it is not without risk. they posited that perhaps the most obvious reasons why commercial real estate merits inclusion in a management portfolio are derived from both cyclical and noncyclical factors - specifically, the favorable longterm outlook for real estate demand, from both users and investors, property cash flows and real estate's potential inflation hedging characteristics. The liquidity of commercial real estate provides investors the most efficient means to obtain exposure to property markets globally. The ability to trade daily not only provides a useful tool for investors to create tactical allocations to the sector and global regions, but it also provides a means to efficiently rebalance allocations as market conditions change (Fiorilla \& Halle, 2011).

Giliberto (1993) asserted that real estate particularly demonstrates different risk and return characteristics depending on: the type of property, the location of the property, and the status of the property in terms of its development. In addition, Steinke (2011) revealed that in real estate investments, characteristics of market, tenancy and the features of the property influences the expectations regarding risks and returns of the investments. Furthermore, Mughees (2010) and Steinke (2011) identified and distinguished real estate' riskreturn strategies as: Core/Core plus (low risk); Value Add (moderate risk) and Opportunistic (high risk). Mughees (2010) posited that the size of the allocation among the real estate risk-return strategies depends on an investor's risk-return appetite, but can generally be in the range of 5\% - 15\%.

\section{Methodology}

Primary data required for this study was obtained through questionnaire survey. The questionnaire was designed in such a way as to elicit for information on the socio-economic characteristics of the respondents as well as the average capital and rental values (per square meter) of commercial real estate investments in Gbongan road, Alekuwodo Road, Station road, Old garage axis and Ola-Iya axis of Osogbo metropolis, Nigeria. The population for the study consisted of all the office and shop properties in the management portfolios of all the 14 estate surveying and valuation firms in the metropolis. The capital and rental values of the selected commercial real estate investments were collected from the principal partners/branch managers of private practicing Estate Surveying and Valuation firms in Osogbo metropolis (this is because the Estate Surveyors and Valuers are the only professionals in Nigeria that are empowered by the law i.e Decree No 24 of 1975 to determine the value of properties and their interest). Total enumeration survey of all the 14 estate surveying firms was conducted. Hence, 14 questionnaires were administered on the Principal/branch managers of the firms. However, only 8 questionnaires were appropriately filled and returned for collation, this represents $57 \%$ response rate. This response rate was considered adequate by the researchers because it's the aggregate averages of the rental and capital values that was used in the study. The data collected was treated as follows:

First, the rental and capital values were used in calculation of the income returns using Equation 1. 
The income return is expressed as follows

$I R_{t}=\frac{N l_{t}}{C V_{t-1}}$

Where:

$\mathrm{IR}_{\mathrm{t}} \quad=$ income return for period $\mathrm{t}$

$\mathrm{NI}_{\mathrm{t}} \quad=$ Net income received in period $\mathrm{t}$ (rent)

$\mathrm{CV}_{\mathrm{t}-1}=\mathrm{CV}$ at the end of period $\mathrm{t}-1$

Second, the capital return was also calculated using Equation 2

The capital return is expressed as

$\mathrm{CR}_{\mathrm{t}}=\frac{c V_{t}-c V_{t-1}}{c V_{t-1}}$

Where:

$\mathrm{CR}_{\mathrm{t}} \quad=$ Capital return for period $\mathrm{t}$

$\mathrm{CV}_{\mathrm{t}}=\mathrm{CV}$ at the start of measurement period

$\mathrm{CV}_{\mathrm{t}-1}=\mathrm{CV}$ at the end of period $\mathrm{t}-1$

Third, both the income and the capital returns were used to determining the total returns.

The total return is expressed as

$T R_{t}=\frac{N I_{t}+\left(C V t-C V_{t-1}\right)}{C V_{t-1}}$

Where

$\mathrm{TR}_{\mathrm{t}}=$ Total return

$\mathrm{CV}_{\mathrm{t}}=$ Capital value of direct property at the beginning

$\mathrm{CV}_{\mathrm{t}-1}=$ Capital value of direct property at the end

$\mathrm{NI}_{\mathrm{t}}=$ Income of direct property received during the holding period

Fourth, the standard deviations of the returns values were calculated. This was used to measure the volatility of the income, capital and total returns which could primarily indicate the risk of investing in office spaces and shops in the study area.

The Asset Risk is expressed as

Asset risk $=\sqrt{\frac{\sum\left(x_{i}-x\right)^{2}}{N}}$

Where:

$\boldsymbol{x}_{\boldsymbol{i}}=$ the asset periodic returns,

$\boldsymbol{x}=$ the mean return and

$\mathbf{N}=$ the number of observations

Fifth, trendlines were used to graphically display trends in the data sets used for this study to help analyze problem of future predictions. Also, the moving average of the trendline was used to smooth out fluctuations in the data and show the pattern or trend more clearly. The $\mathrm{R}^{2}$ value was used to determine the reliability of the trend and the accuracy of the forecast or predictions made. A trendline is said to be most accurate when its RSquared value is at or near 1. Similarly, least square linear regression equations were generated for prediction of future rental, capital and returns values. These are the equations of a straight line that best fits the points on the chart. The method used to determine these equations involves finding the line that produces the least value for the sum of the squares of the vertical differences between data points and the line.

The equation is in the form:

$y=m x+b$ 
where:

$\boldsymbol{y}$ is the dependent variable (rental, capital or returns values as the case may be)

$\boldsymbol{m}$ is the slope of the line, which equals the change in the $y$ value divided by the change in the $x$ value;

$\boldsymbol{x}$ is the dependent variable (year in this case); and

$\boldsymbol{b}$ is the $y$-axis intercept of the line.

Finally, a comparative analysis of the return-risk characteristics of commercial real estate investments in the study area was carried out.

\section{Results and Discussion}

This section presented the results from analysis of data obtained for the study and subsequently discusses the results accordingly. First, the respondents profile was presented and analyzed. Second, the average rental/capital values (per meter square) of commercial property investments in the study area within the period was calculated and presented. Third, the income, capital and total returns from the said investments were accordingly calculated. Fourth, the risk characteristics of the asset classes in question were also calculated and accordingly analyzed. Finally, the section concluded with a comparative analysis of the return-risk profiles of commercial real estate investments in the study area.

Table 1: Respondents' profile

\begin{tabular}{|c|c|c|c|}
\hline $\begin{array}{l}\text { Respondents' } \\
\text { Characteristics }\end{array}$ & Status & Frequency & Percentage \\
\hline \multirow{5}{*}{$\begin{array}{l}\text { Position } \\
\text { in the } \\
\text { firm }\end{array}$} & principal partner & 6 & 75 \\
\hline & associate partner & 0 & 0 \\
\hline & branch manager & 2 & 25 \\
\hline & head of Department & 0 & 0 \\
\hline & Total & 8 & 100 \\
\hline \multirow{6}{*}{$\begin{array}{l}\text { Educational } \\
\text { qualification }\end{array}$} & OND & 0 & 0 \\
\hline & HND & 3 & 37 \\
\hline & B.Sc/B. Tech & 4 & 50 \\
\hline & MSc/M. Tech & 1 & 13 \\
\hline & $\mathrm{PhD}$ & 0 & 0 \\
\hline & Total & 8 & 100 \\
\hline \multirow{5}{*}{$\begin{array}{l}\text { Professional } \\
\text { qualification }\end{array}$} & FNIVS & 1 & 13 \\
\hline & ANIVS/RSV & 4 & 50 \\
\hline & ANIVS & 2 & 24 \\
\hline & Probationer & 1 & 13 \\
\hline & Total & 8 & 100 \\
\hline \multirow{5}{*}{$\begin{array}{c}\text { Years of } \\
\text { Professional } \\
\text { practice }\end{array}$} & $1-11 y r s$ & 3 & 37 \\
\hline & $12-21 y r s$ & 4 & 50 \\
\hline & $22-31 y r s$ & 1 & 13 \\
\hline & above $31 \mathrm{yrs}$ & 0 & 0 \\
\hline & Total & 8 & 100 \\
\hline
\end{tabular}

Source: Authors' Field Survey, 2013

Table 1 showed the profile of the respondents who supplied data on rental and capital values in terms of their: position in the Estate Firm, educational qualification, professional qualification and years of professional practice as Estate Surveyors and Valuers. This was done in order to ascertain the validity and reliability of the data collected for the study.

Table 2 presents the average rental values in Naira $\left(\right.$ per $\mathrm{m}^{2}$ ) of office and shop properties in Gbongan road, Alekuwodo road, Station road, Old garage axis and Ola-Iya area of Osogbo metropolis. 
Table 2: Average Rental Values in $\left(\right.$ per $\mathrm{m}^{2}$ ) of Office and Shop properties in Osogbo $(2002-2012)$

Source: Authors' Field Survey, 2013

\begin{tabular}{|c|c|c|c|c|c|c|c|c|c|c|c|c|}
\hline \multirow{2}{*}{$\begin{array}{l}\text { Property } \\
\text { Type } \\
\end{array}$} & \multirow[b]{2}{*}{ Property Location } & \multicolumn{11}{|c|}{ Year } \\
\hline & & 2002 & 2003 & 2004 & 2005 & 2006 & 2007 & 2008 & 2009 & 2010 & 2011 & 2012 \\
\hline \multirow{6}{*}{ 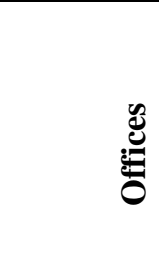 } & Gbongan Road & 1005 & 1315 & 1452 & 2102 & 2518 & 3982 & 4006 & 4321 & 4443 & 6321 & 7127 \\
\hline & Alekuwodo Road & 988 & 997 & 1003 & 2112 & 2247 & 2854 & 3354 & 3542 & 3649 & 4008 & 5342 \\
\hline & Station Road & 711 & 752 & 790 & 1053 & 1322 & 1602 & 2543 & 2786 & 2866 & 3213 & 3398 \\
\hline & Old garage axis & 1276 & 1376 & 1564 & 1786 & 1876 & 2755 & 3112 & 3655 & 3897 & 4322 & 6554 \\
\hline & Ola-Iya axis & 1121 & 1235 & 1356 & 1564 & 1987 & 2675 & 3766 & 4876 & 5755 & 6334 & 7189 \\
\hline & Average & 1020 & 1135 & 1233 & 1723 & 1990 & 2774 & 3356 & 3836 & 4122 & 4840 & 5922 \\
\hline \multirow{6}{*}{$\frac{n}{0}$} & Gbongan Road & 511 & 543 & 598 & 654 & 677 & 711 & 723 & 789 & 1098 & 2544 & 3221 \\
\hline & Alekuwodo Road & 632 & 678 & 702 & 722 & 750 & 906 & 987 & 1055 & 1234 & 1298 & 3544 \\
\hline & Station Road & 498 & 566 & 623 & 765 & 778 & 895 & 1011 & 2112 & 2566 & 2655 & 2786 \\
\hline & Old garage axis & 513 & 533 & 576 & 654 & 687 & 811 & 865 & 1006 & 1522 & 1590 & 2136 \\
\hline & Ola-Iya axis & 489 & 522 & 543 & 653 & 702 & 798 & 943 & 998 & 1013 & 1654 & 1786 \\
\hline & Average & 529 & 568 & 608 & 690 & 719 & 824 & 906 & 1192 & 1487 & 1948 & 2695 \\
\hline
\end{tabular}

Source: Authors' Field Survey, 2013

The rental values in Table 2 were arrived at by calculating for each year respectively, the aggregate total averages of all the respondents' responses in the study area per meter square. For both office and shop properties, the rental values was observed to be higher along Gbongan and Station road of the metropolis and lowest along Station road for offices and along Ola-iya axis for shops.

Figure 1 presents the trend analysis of the average rental values of both office and shop properties in Osogbo between 2002 and 2012.

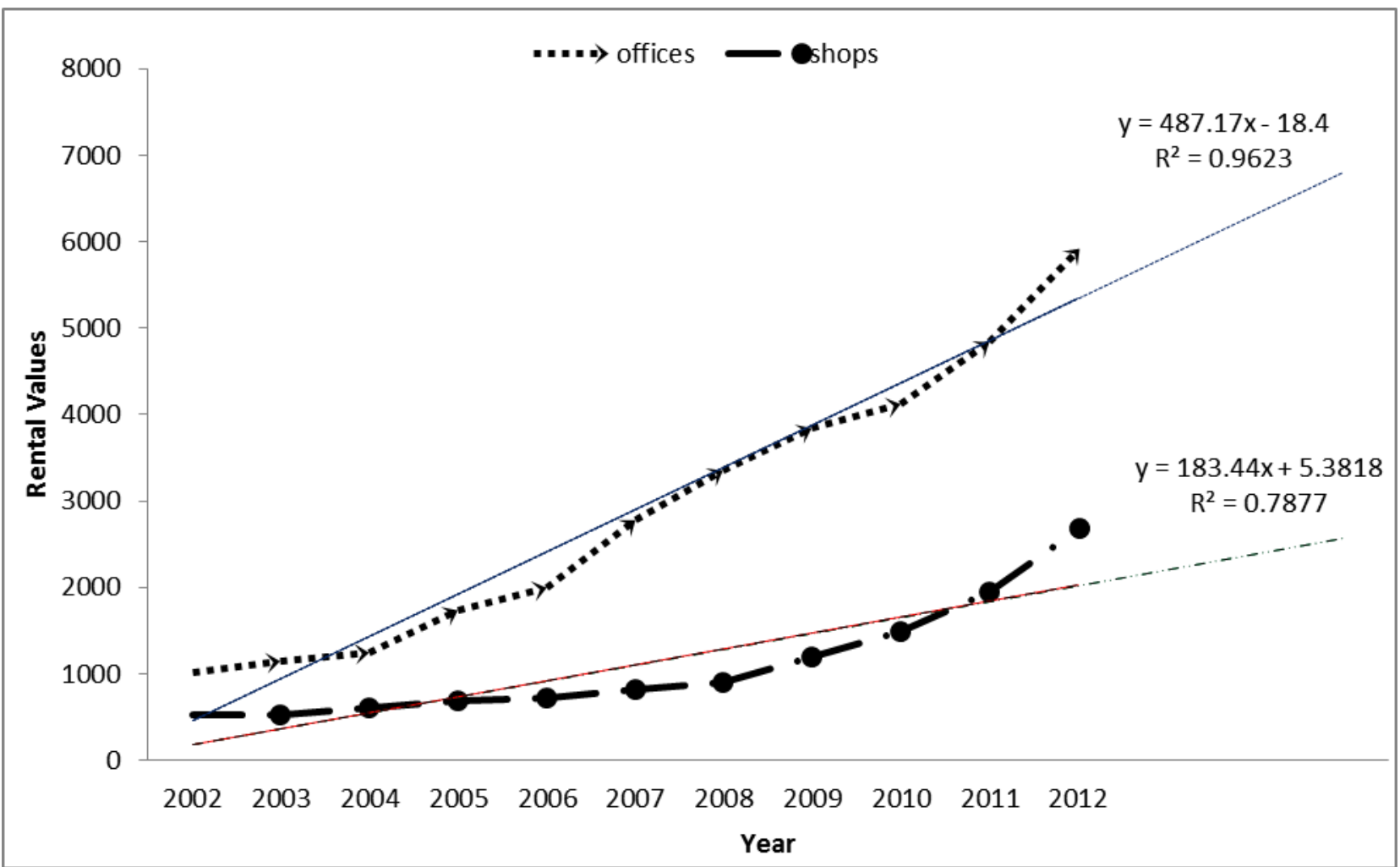

Figure1: Trend Analysis of Rental Values in Osogbo

For both property types, the trendlines indicated a consistent and steady increase from 2002 to 2012 . There was a wide margin in the growth rate of office and shop property types in the study area, with the office property type indicating a far better growth rate. This is an indication that investment in office properties could be a better option than investment in shop properties in the study area. A future forecast with respect to rental values of 
commercial properties in the study area for additional three years from 2012 was made. The analysis indicated continues steady increase of rental values for both office and shop properties for the next three years with the office property type exhibiting a better growth rate throughout the prediction period. The level of reliability of the trend and accuracy of the forecast as determined by the $\mathrm{R}^{2}$ value for both property types is as follows: For the office property, the level of reliability and accuracy of the forecast is $96.23 \%$, while that of the shop property type is $78.77 \%$. From the analysis above, it can be inferred that rental values of office and shop properties in the study area had a steady and consistent growth over the study period and this growth is likely to be maintained over the next three years as seen from the predictive trendlines. The office property type in Osogbo showed a better growth rate than shop property type in the predictive years.

The capital values obtained for this study were also analyzed. Similarly, the capital values used in the study were also obtained from the valuation based indices of commercial properties in the study areas. The capital values obtained from the prime commercial areas of the study areas respectively were derived on per meter square basis and presented in Table 3.

Table 3 showed the average capital values in Naira $\left(\right.$ per $\mathrm{m}^{2}$ ) of office and shop properties in Gbongan road, Alekuwodo road, Station road, Old garage axis and Ola-Iya axis of Osogbo metropolis.

Table 3: Average Capital Values in $\left(\right.$ per $\mathrm{m}^{2}$ ) of Office and Shop properties in Osobgo

\begin{tabular}{|c|c|c|c|c|c|c|c|c|c|c|c|c|c|}
\hline \multirow[b]{3}{*}{ Property Type } & \multirow[b]{3}{*}{ Property Location } & \multicolumn{12}{|c|}{ Year } \\
\hline & & 2001 & & & & & & & & & & & \\
\hline & & & 2002 & 2003 & 2004 & 2005 & 2006 & 2007 & 2008 & 2009 & 2010 & 2011 & 2012 \\
\hline \multirow{7}{*}{ : } & & 16100 & & & & & & & & & & & \\
\hline & Gbongan Road & 20800 & 16125 & 17834 & 18171 & 19321 & 20135 & 22678 & 30876 & 34567 & 36123 & 37347 & 38997 \\
\hline & Alekuwodo Road & & 20831 & 21665 & 22876 & 23657 & 27865 & 29876 & 30879 & 30998 & 31234 & 37876 & 41324 \\
\hline & Station Road & $\begin{array}{l}27800 \\
10155\end{array}$ & 27886 & 28764 & 29456 & 31675 & 33453 & 33699 & 33786 & 33998 & 34987 & 35463 & 35898 \\
\hline & Old garage axis & & 17213 & 18765 & 19564 & 20453 & 20987 & 25765 & 29782 & 33543 & 36874 & 38342 & 41678 \\
\hline & Ola-Iya axis & $\begin{array}{r}25000 \\
19971\end{array}$ & 28002 & 29876 & 30876 & 32546 & 32987 & 33453 & 34213 & 35675 & 37654 & 39876 & 40786 \\
\hline & Average & & 22011 & 23381 & 24189 & 25530 & 27085 & 29094 & 31907 & 33756 & 35374 & 37781 & 39737 \\
\hline \multirow{7}{*}{ 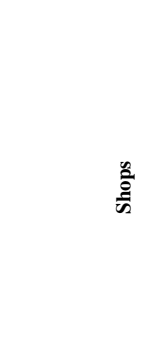 } & & 7700 & & & & & & & & & & & \\
\hline & Gbongan Road & 12000 & 7735 & 7986 & 8354 & 8675 & 9543 & 10564 & 15677 & 19342 & 27543 & 30443 & 33567 \\
\hline & Alekuwodo Road & 11000 & 12056 & 13543 & 13987 & 14221 & 15678 & 17654 & 20786 & 21345 & 22453 & 23786 & 24332 \\
\hline & Station Road & 10665 & 11032 & 11765 & 12435 & 12987 & 13768 & 14008 & 17564 & 19786 & 20564 & 22343 & 23768 \\
\hline & Old garage axis & 8500 & 13768 & 14321 & 14987 & 15443 & 15987 & 17865 & 20654 & 22341 & 24876 & 26459 & 27865 \\
\hline & Ola-Iya axis & 9973 & 8945 & 9354 & 9564 & 10675 & 11677 & 13657 & 19876 & 22348 & 27880 & 28765 & 29008 \\
\hline & Average & & 10707 & 11394 & 11865 & 12400 & 13331 & 14750 & 18911 & 21032 & 24663 & 26359 & 27708 \\
\hline
\end{tabular}

Source: Authors' Field Survey, 2013

The capital values presented in Table 3 were likewise arrived at by calculating for each year respectively, the aggregate total averages of all the respondents' responses in the study area per meter square. The highest capital values for both office and shop properties were obtained in 2012. The lowest capital values were recorded in the year 2002. For all the prime commercial areas in Osogbo the highest capital values was obtained in Old garage axis ( 41,678$)$ in the year 2012 while the highest for shops was obtained in Gbangang road $(\$ 33,567)$ in the year 2012 .

Figure 2 showed the trend analysis of the average capital values of both office and shop properties in Osogbo between 2002 and 2012 . 


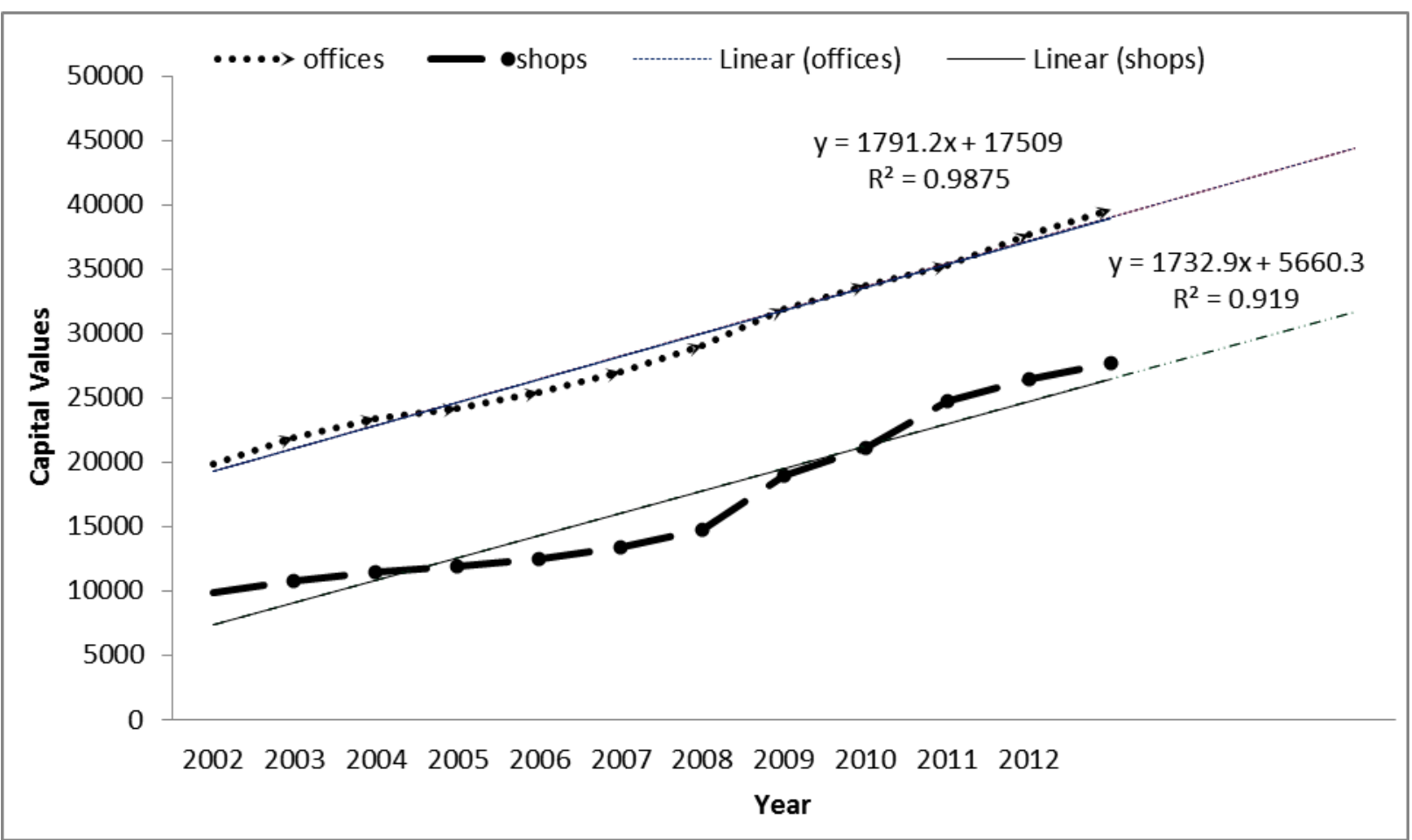

Figure 2: Trend Analysis of Capital Values in Osogbo

Figure 2 showed that for both property types, the trendlines indicated a consistent and steady increase from 2002 to 2012. The office property type indicated a better growth rate than the shop property type throughout the study period. A future forecast with respect to the capital values of commercial properties in the study area for additional three years from 2012 was also made. The analysis indicated continues steady increase of capital values for both office and shop properties for the next three years with the office property type exhibiting a better growth rate. The level of reliability of the trend and accuracy of the forecast as determined by the $\mathrm{R}^{2}$ value for both property types is as follows: For the office property, the level of reliability and accuracy of the forecast is $98.75 \%$, while that of the shop property type is $91.90 \%$. From the analysis above, it can be inferred that capital values of office and shop properties in the study area had a steady and consistent growth rate over the study period and this growth rate is likely to be maintained over the next three years as seen from the predictive trendlines.

As mentioned earlier, the income, capital and total returns for both office and shop properties in Osogbo were calculated using Equations 1, 2 and 3. These are presented in Table 4 accordingly.

Table 4 presented the income, capital and total returns on office and shop property investments in the study area within the study period. 
Table 4: Income Return (IR), Capital Return (CR) and Total Returns (TR) on Office and shop Properties in the Study area

\begin{tabular}{|c|c|c|c|c|c|c|}
\hline \multirow{3}{*}{ Year } & \multicolumn{2}{|c|}{ Income Returns } & \multicolumn{2}{|c|}{ Capital Returns } & \multicolumn{2}{|c|}{ Total Returns } \\
\hline & Offices & Shops & Offices & Shops & Offices & Shops \\
\hline & IR $(\%)$ & IR $(\%)$ & $\mathrm{CR}(\%)$ & $\mathrm{CR}(\%)$ & TR $(\%)$ & TR $(\%)$ \\
\hline 2002 & 4.64 & 4.94 & 10.19 & 7.42 & 14.83 & 12.36 \\
\hline 2003 & 5.16 & 5.30 & 6.22 & 6.42 & 11.38 & 11.72 \\
\hline 2004 & 5.27 & 5.34 & 3.46 & 4.13 & 8.73 & 9.47 \\
\hline 2005 & 7.12 & 5.82 & 5.57 & 4.51 & 12.69 & 10.33 \\
\hline 2006 & 7.79 & 5.80 & 6.10 & 7.51 & 13.89 & 13.31 \\
\hline 2007 & 10.24 & 6.18 & 7.42 & 10.78 & 17.66 & 16.96 \\
\hline 2008 & 11.54 & 6.14 & 9.66 & 28.21 & 21.20 & 34.35 \\
\hline 2009 & 12.03 & 6.30 & 5.79 & 11.22 & 17.82 & 17.52 \\
\hline 2010 & 12.21 & 7.07 & 4.79 & 17.27 & 17.00 & 24.34 \\
\hline 2011 & 13.68 & 7.90 & 6.81 & 6.88 & 20.49 & 14.78 \\
\hline 2012 & 14.90 & 10.22 & 5.95 & 3.12 & 20.85 & 13.34 \\
\hline Weighted Average & 9.51 & 6.46 & 6.54 & 9.77 & 16.05 & 16.23 \\
\hline
\end{tabular}

Source: Analysis of Survey data, 2013

From Table 4 the highest income return was obtained from office properties as shown by a weighted average of $9.51 \%$ against $6.46 \%$ demonstrated by shop properties. Similarly, for the capital returns the highest weighted average was seen in shop properties $(9.77 \%)$ as against the office properties $(6.54 \%)$. The total returns revealed that investments in shop properties in the study area provided better returns $(16.23 \%)$ than investments in office properties $(16.05 \%)$.

Table 5 presented the risk profile of investments in both office and shop properties in the study area. This was calculated using Equation 4.

Table 5: Risk profile of investments in office and shop properties in the study area

\begin{tabular}{ccc}
\hline Property & Std. & Rank \\
Type/Returns & Deviation & 4 \\
\hline Office IR & 3.66 & 6 \\
Shop IR & 1.50 & 5 \\
& & 2 \\
Office CR & 1.96 & 2 \\
Shop CR & 7.30 & 1 \\
Office TR & 10.11 & 3 \\
Shop TR & 7.23 & \\
\hline
\end{tabular}

Source: Analysis of Survey data, 2013

Table 5 showed the risk characteristics of investments in commercial real estate in the study area. From Table 5, the level of riskiness from the highest to the lowest is as follows: office properties $10.11 \%$ (total returns); shop properties $7.30 \%$ (capital returns); shop properties $7.23 \%$ (total returns); office properties $3.66 \%$ (income returns); office properties $1.96 \%$ (capital returns) and shop properties $1.50 \%$ (income returns) respectively. 
Table 6: Comparative analysis of return and risk profiles of commercial real estate investments in Osogbo (20022012)

\begin{tabular}{|c|c|c|c|c|c|c|}
\hline $\begin{array}{c}\text { Property } \\
\text { Type/ } \\
\text { Returns } \\
\end{array}$ & $\begin{array}{l}\text { Minimum } \\
\text { Return }\end{array}$ & $\begin{array}{c}\text { Maximum } \\
\text { Return }\end{array}$ & $\begin{array}{l}\text { Weighted } \\
\text { Return }\end{array}$ & $\begin{array}{c}\text { Rank } \\
\text { (Weighted Return) }\end{array}$ & Std. Deviation & Rank (Std. Deviation) \\
\hline Office IR & 4.64 & 14.90 & 9.50 & 4 & 3.66 & 4 \\
\hline Shop IR & 4.94 & 10.22 & 6.45 & 6 & 1.50 & 6 \\
\hline Office CR & 3.46 & 10.19 & 6.54 & 5 & 1.96 & 5 \\
\hline Shop CR & 3.12 & 28.21 & 9.77 & 3 & 7.30 & 2 \\
\hline Office TR & 8.73 & 21.2 & 16.31 & 2 & 10.11 & 1 \\
\hline Shop TR & 9.47 & 34.35 & 16.40 & 1 & 7.23 & 3 \\
\hline
\end{tabular}

Source: Analysis of Survey Data, 2013

From Table 6, the highest returns obtained $(16.40 \%)$ has a corresponding third level of risk $(7.23 \%)$, while the lowest returns obtained $(6.45 \%)$ had a corresponding lowest level of risk (1.50\%). The risk bearing capacity of office and shop properties in the study area presents a unique opportunity for investors to shield their investment portfolios from risk complexities and the inherent uncertainties associated with it. Another unique characteristics of commercial properties which investors can consider as an advantage of including commercial properties in their investment portfolios is its return profile. The return and risk characteristics of an investment asset are key rationale for investing in commercial real estate in order to maximize profits and minimize as well as spread investment risk in a mixed-asset portfolio.

\section{Summary of Findings, Implication and Conclusion}

The study examined the risk-return characteristics of commercial real estate investments in Osogbo metropolis Nigeria. The study covered the period between 2002 and 2012. Findings from the study showed that investments in both office and shops properties provided a continuous positive rate of returns throughout the study period. The highest return obtained within the study period was $34.35 \%$ and the lowest was $3.12 \%$. Similarly, the highest level of risk was $10.11 \%$ while the lowest was $1.50 \%$.

This Study provided investment information with respect to commercial real estate in Osogbo metropolis. The investment information provided in this study has significant implication for both local and foreign investors desiring to invest in the Nigerian property market. This research enables empirically validated, more informed and practical property investment decision-making with respect to selection of assets for a proper and appropriate investment portfolio mix so as to enhance portfolio performance by obtaining highest returns with possible minimal risk.

\section{References}

Ballantine J. \& Stray S. (1998). Financial appraisal and the ICT investment decision makingprocess. Journal of Information Technology, 14, 3-15.

Conner, P. (2010). Revisiting the case for commercial real estate. Retrieved from: http://www2.prudential.com/o\&s/prei.nsf/14ef712a6b099d9d852566ef005111d0/e79e025e0aa5c171852 5772d006f7cf7/\$FILE/Revisiting\%20CRE\%20PRU.pdf

Fiorilla, P. \& Halle, M. (2011). Market opportunities in global real estate securities. Retrieved from http://www.investmentmanagement.pramerica.com/media/managed/documents/pim_pramerica/GRES_ Opp_PRA_0511.pdf

Georgie. \& Georgi. (2003). Benefits of real estate investment. Journal of Portfolio Management, 29(5), 28-33. Giliberto, S.M. (1993). Measuring real estate returns: the hedged REIT index, Journal of Portfolio Management, Spring, 94-99.

Hoesli, M. \& Lekander, J. (2008). Real estate portfolio strategy and product innovation in Europe. Journal of Property Investment \& Finance, 26 (2), 162-176.

Hui, Eddie, C.M. (2009). Jump point detection for real estate investment success. Physica A: Statistical Mechanics and its Applications, 389(5), 1055-1064.

Koen, M., Monique, S., Raf, H. (2010). Evaluation of the applicability of investment appraisal techniques for 


assessing the business value of IS Retrieved

https://lirias.kuleuven.be/bitstream/123456789/247210/1/KBI_0910.pdf

Mughees, S. (2010). The benefits and importance of commercial real estate. Retrieved from http://mpra.ub.unimuenchen.de/28268

Ruhmann, S. \& Woolston, C. (2011). US Private core real estate investing. Retrieved from http://www.nepc.com/writable/research_articles/file/2011_10_nepc_us_private_core_real_estate investing.pdf Steinke, C. (2011). Analysis of different dimensions for property allocation process within real estate investment companies. A Master thesis submitted to KTH Royal Institute of Technology, KTH Architecture and the Build Environment, Department of Real Estate and Construction Management. Retrieved from http://www.kth.se/polopoly_fs/1.273432!/Menu/general/columncontent/attachment/Steinke\%20C\%20Property\%20allocation\%20process \%20within \%20real\%20estate\%20invest ment.pdf

Marquard, A., \& Von-Eije, J. H. (2006). Measuring risk for private property funds. Retrieved from http://www.vastgoedkennis.nl/docs/scripties/Rothweiler.pdf

Payton, M. (2011a). Is commercial real estate a hedge against inflation? Retrieved from: http://tcasset.org/sites/default/files/tcam iscommrehedgeagainstinflation.pdf

Thambiah, Y., \& Foscari, N. (2011). Real Assets: Inflation Hedge Solution Under a Modified Risk Framework. Retrieved from https://www.creditsuisse.com/asset_management/doc/thought leadership/real_assets_white_paper_201109_en.pdf 